\title{
Receptor Modelling of particulate matter at residential area near industrial region in Indonesia using Positive Matrix Factorization
}

\author{
Seny Damayanti ${ }^{1,}$, and Puji Lestari ${ }^{2 *}$ \\ 1,2 Department of Environmental Engineering, Bandung Institute of Technology (ITB), Jl.Ganesha No.10, Bandung 40132, Indonesia
}

\begin{abstract}
Positive Matrix Factorization (PMF) was used to identify the sources of ambient TSP and to estimate respective contribution to the total ambient TSP concentration in the residential area surrounding iron and steel industry in Cilegon city. Total of 34 daily samples ( 24 hours) were collected during the sampling period (August-November 2015) using a High Volume Sampler. The samples then were analyzed for black carbon and 18 metal elements ( $\mathrm{Si}, \mathrm{Al}, \mathrm{Fe}, \mathrm{S}, \mathrm{Cu}, \mathrm{Pb}, \mathrm{V}, \mathrm{Cr}, \mathrm{Ni}, \mathrm{Zn}, \mathrm{Mn}, \mathrm{Sn}, \mathrm{K}, \mathrm{Ca}, \mathrm{Cl}, \mathrm{Ti}, \mathrm{Ba}$, and $\mathrm{Co}$ ) using Diffusion Systems EEL 43m Smoke Stain Reflectometer (SSR) and Energy Dispersive X-Ray Fluorescence (ED-XRF), respectively. From the PMF results were found that 10 factors as the optimum solution. The five major sources are crustal matter (40.13\%), iron and steel production (22.23\%), coal combustion (16.54\%), biomass burning $(11.83 \%)$, smelting $(8.63 \%)$. Meanwhile, the other sources detected are diesel vehicle $(0.28 \%)$, sea salt $(0.17 \%)$, fuel-oil combustion $(0.07 \%)$, road dust $(0.07 \%)$, and cement industries /construction $(0.05 \%)$. The patterns of conditional probability function analysis results were adequately appropriate with the potential locations of the known sources around study site.
\end{abstract}

\section{Introduction}

Particulate matter discharged into the atmosphere from natural sources such as soil erosion, sea spray, natural forest fire and volcanic activity, as well as from anthropogenic sources like traffic emission, combustion of fossil fuel, residential heating, biomass burning and activities from industries [1]. This pollutant is one of the key pollutants which have an adverse impact on human health [2]. Besides, toxic or acidic substances such as heavy metals and a carcinogenic organic compound which is likely carried by particulate matter could lead to negative impact not only on human health but also on ecosystems $[3 ; 4 ; 5]$.

Source apportionment and identification of pollutant are very important steps in air quality management [6]. One of the approaches to attain this step is by using receptor model. In receptor model, chemical and physical characteristics of gases and particles measured at source and receptor are used to identify emission sources as well as quantify its contribution to the ambient air [5]. Receptor model is complementary of source model (dispersion model) in air quality assessment which used the ambient concentration to identify the source emission, while dispersion model is used to predict ambient concentration from the emission data. This model has been effectively implemented for developing of air quality management plans in various cities [7]. Positive Matrix Factorization (PMF) is widely used in receptor modelling analysis [8]. In addition, it is one of a multivariate statistical method based on factor analysis which has been specifically developed for source apportionment purpose which used air quality data [2]. Cilegon city located in Banten Province is one of the main areas of industrial development in Indonesia due to its geographically strategic location on the international cruise lines. Moreover, Cilegon is a major western gateway of Java which connects directly to the Island of Sumatra and the neighbouring countries [9]. The development of this industry has potentially causing impact to the public health and the surrounding ecosystem. The existence of various industries, the dense transportation activities, as well as natural emission sources in Cilegon city, can be a potential source of particulate emissions. The complaint because of air pollution which was mainly caused by TSP arose from the community around this industrial area, particularly they who live close to the iron and steel industry. However, study related air quality especially about source apportionment has not been done yet. Therefore, this study aimed to conduct source apportionment to identify the sources of ambient TSP and to estimate the respective contribution to the total ambient TSP concentration in the residential area surrounding iron and steel industry in Cilegon city using PMF receptor model. The results of this study are expected to be a reference in particular for industry and policy makers to deal with air pollution problem in Cilegon city.

\footnotetext{
* Corresponding author: pujilest@indo.net.id
} 


\section{Methods}

\subsection{Sampling equipment}

A total 34 daily TSP samples were collected using a High Volume Sampler (HVS) with glass micro fibre filter EPM 2000 at flow rate $1.3 \mathrm{lpm}$. There was a pre-sampling treatment to the filters that were conditioned for 24 hours in a desiccator then were weighed to get an initial weight of the filter. The sampling equipment placed on a platform with a height about 1.5 meters from the ground. Meteorological parameters such as wind direction, wind speed, pressure, humidity, and temperature were measured using a sling psychrometric, compass, barometer, and anemometer, respectively.

\subsection{Location of Sampling}

Samples were collected in the residential area close to iron and steel industrial regions in Cilegon city in Banten Province, Indonesia. Several things which were considered to determine a sampling site that was, meteorological factors (wind speed and direction), topography, historical considerations, and the availability of power supply. The sampling location is shown in Figure 1.

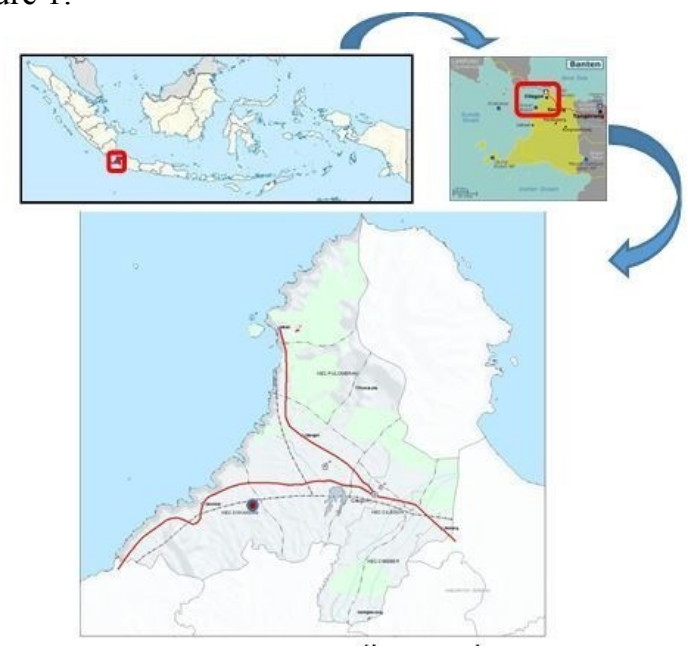

Fig 1. Sampling Location

\subsection{Sampling Time}

Total of 34 daily samples of TSP were collected in 34 days during sampling period, August-November 2015.

\subsection{Sample's Analysis}

Samples analysis were carried out in several steps. TSP concentration analysis was conducted by a gravimetric method, and analysis of Black Carbon (BC) was done by using EEL Smoke Stain Reflectometer Model 43D (SSR). Meanwhile, metal elements composition ( $\mathrm{Si}, \mathrm{Al}$, Fe, S, $\mathrm{Cu}, \mathrm{Pb}, \mathrm{V}, \mathrm{Cr}, \mathrm{Ni}, \mathrm{Zn}, \mathrm{Mn}, \mathrm{Sn}, \mathrm{K}, \mathrm{Ca}, \mathrm{Cl}, \mathrm{Ti}, \mathrm{Ba}$, and $\mathrm{Co}$ ) were analysed using Energy Dispersive $\mathrm{X}$ - ray Fluorescence (ED-XRF).

\subsection{Data Analysis by PMF}

Matrix X with dimension $\mathrm{m}$ columns and $\mathrm{n}$ rows, where $\mathrm{m}$ is the number of species and $\mathrm{n}$ is the number of samples, can be factorized by using PMF into matrix $G(n \times p)$ and matrix $\mathrm{F}(\mathrm{p} \mathrm{x} \mathrm{m})$, and also matrix $\mathrm{E}$ which is the residual [8] as shown in Equation 1. As for $p$ is the number of sources or factors, matrix $G$ is source contribution and matrix $F$ is source profiles. This source profiles are then interpreted by the analyst [10] to determine source types by comparing with source profile from literature. In source apportionment study including PMF, a term of a factor is usually interpreted as a source [11]. The aims of this analysis are to find the values of $G, F$, and $p$ which yielded the best of $X$.

$$
X=G F+E
$$

Next step is to reduce $Q$ value as a function of $G$ and $\mathrm{F}$, where there is the constraint of all element of matrix $G$ as well as matrix $F$ to be nonnegative [8]. Q is defined as shown in Equation 2:

$$
Q=\sum_{i=1}^{n} \sum_{j=1}^{m}\left(\frac{e_{i j}}{\sigma_{i j}}\right)^{2}
$$

$\sigma_{\mathrm{ij}}$ is the uncertainty of the $j_{\text {th }}$ species concentration of sample i [11]. Several FPeak values (rotating matrix parameter) were also explored to determine a reasonable solution [12]. The Goodness of fit model are measured from $Q$ value analysis, distribution of residual frequency, and the multiple linear regression results of reconstructed mass concentration [13].

Conditional probability function is an approach that usually used to find the sources probably located. It is also can be applied to investigate the effect of wind direction on each source [14]. The CPF for each source is define as following equation:

\section{(3)}

$$
\mathrm{CPF}=\mathrm{m}_{\Delta \theta} / \mathrm{n}_{\Delta \theta}
$$

Where $m_{\Delta \theta}$ is the occurrence number of fractional contribution that exceeding the threshold, while $n_{\Delta \theta}$ is the occurrences of the total number of wind direction in the same sector [14]. 24 sectors of wind direction was used in this study $\left(\Delta \theta=15^{\circ}\right)$, and all the calm wind data (wind with speed below $1 \mathrm{~ms}^{-1}$ ) were excluded from the analysis. The direction sector with high CPF values is considered as the potential location of emission source.

\section{Results and Discussion}

\subsection{Source Profile}

A Total of 34 TSP samples was collected during the sampling period (August-November 2015) in a residential area in Cilegon city, Banten Province. Gravimetric analysis result shows that the average TSP concentration was $187.35 \pm 42.68 \mu \mathrm{g} / \mathrm{m}^{3}$ with a minimum and maximum concentration was 100.31 and $297.86 \mu \mathrm{g} / \mathrm{m}^{3}$, respectively. Besides, there were three samples that exceed the national ambient air quality standards, from Government Regulation No 41 year $1999\left(230 \mu \mathrm{g} / \mathrm{m}^{3}\right)$. The average 
concentration of TSP, metal elements and Black Carbon with standard deviation and percentage of each element contained by TSP are listed in Table 1 .

Table 1. The mean and standard deviation of TSP, metal element, and $\mathrm{BC}$ in $\mu \mathrm{g} / \mathrm{Nm}^{3}$.

\begin{tabular}{|l|c|c|c|}
\hline & Mean & SD & Range \\
\hline $\mathrm{TSP}$ & 187.35 & 42.68 & $100.31-297.86$ \\
\hline $\mathrm{BC}$ & 2.45 & 1.17 & $1.39-5.14$ \\
\hline $\mathrm{S}$ & 1.60 & 0.63 & $0.63-2.95$ \\
\hline $\mathrm{Cl}$ & 1.00 & 0.46 & $0.52-2.29$ \\
\hline $\mathrm{K}$ & 0.39 & 0.11 & $0.20-0.70$ \\
\hline $\mathrm{Cr}$ & 0.01 & 0.00 & $0.00-0.02$ \\
\hline $\mathrm{Fe}$ & 6.66 & 2.20 & $3.63-12.02$ \\
\hline $\mathrm{Co}$ & 0.00 & 0.00 & $0.00-0.00$ \\
\hline $\mathrm{Ni}$ & 0.01 & 0.01 & $0.00-0.06$ \\
\hline $\mathrm{Cu}$ & 4.14 & 2.60 & $1.46-14.81$ \\
\hline $\mathrm{Pb}$ & 0.07 & 0.04 & $0.02-0.21$ \\
\hline $\mathrm{Ca}$ & 1.40 & 0.93 & $0.02-4.56$ \\
\hline $\mathrm{Ti}$ & 0.33 & 0.11 & $0.15-0.62$ \\
\hline $\mathrm{V}$ & 0.02 & 0.01 & $0.01-0.04$ \\
\hline $\mathrm{Mn}$ & 0.24 & 0.10 & $0.10-0.50$ \\
\hline $\mathrm{Zn}$ & 0.30 & 0.12 & $0.12-0.73$ \\
\hline $\mathrm{Ba}$ & 0.07 & 0.03 & $0.02-0.13$ \\
\hline $\mathrm{Sn}$ & 0.02 & 0.03 & $0.00-0.13$ \\
\hline $\mathrm{Al}$ & 3.74 & 1.81 & $1.67-9.68$ \\
\hline $\mathrm{Si}$ & 27.87 & 10.82 & $10.67-64.30$ \\
\hline
\end{tabular}

It can be seen that $\mathrm{Si}, \mathrm{Fe}, \mathrm{Cu}, \mathrm{Al}, \mathrm{BC}, \mathrm{S}$ and $\mathrm{Ca}$ have a significant concentration compared to the other elements, with a mean concentration were $27.87 \mu \mathrm{g} / \mathrm{m}^{3}, 6.66 \mu \mathrm{g} / \mathrm{m}^{3}$, $4.12 \mu \mathrm{g} / \mathrm{m}^{3}, 3.74 \mu \mathrm{g} / \mathrm{m}^{3}, 2.45 \mu \mathrm{g} / \mathrm{m}^{3}, 1.6 \mu \mathrm{g} / \mathrm{m}^{3}$ and 1.4 $\mu \mathrm{g} / \mathrm{m}^{3}$, respectively. Meanwhile for other elements were equal or less than $1 \mu \mathrm{g} / \mathrm{m}^{3}$. It also shows that the total concentration of analysed element (metal and BC) was $27 \%$ from TSP concentration. The meteorological data were also collected from local station. It can be seen from the wind rose (Figure 2) that the dominant wind direction for Cilegon region is derived from North with calm wind frequency was $59.69 \%$.

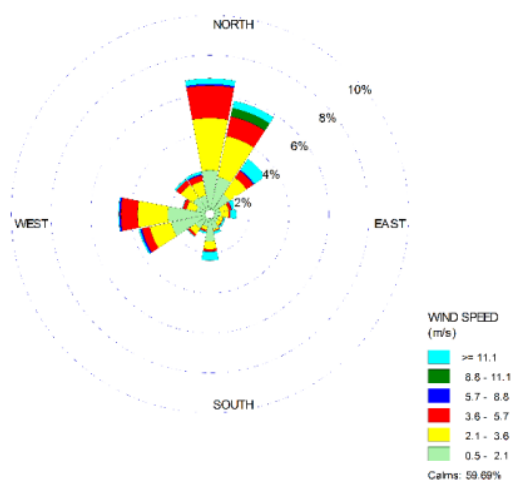

Fig 2. Annual wind rose
The concentration and uncertainty matrices were used as input to PMF. In this study, PMF was run with the various number of factors starting from 7 to 11 to obtain the optimum number of sources. Determination of factor number is based on the analysis of Q value, the frequency distribution of the scaled residual and regression results of multiple linear regression of reconstructed concentration with measured concentrations. It is considered as a good starting point when a result of PMF produce $Q$ value that closest to the Q theory [11], so ten factors were then chosen as can be seen from Figure 3 .

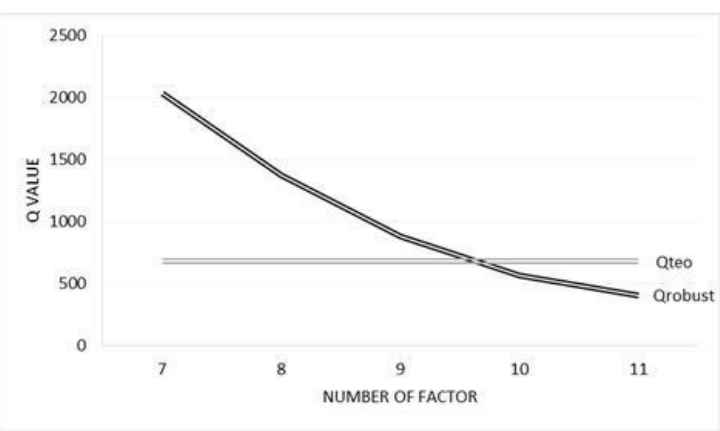

Fig. 3. Plot of $Q$ value from various number of factors

The other consideration to decide the best solution is a parameter to control rotation called FPEAK. Generally, the most interpretable physically source profile yielded from the highest FPeak before the significant rise of $Q$ value [15]. Hence, FPeak $=0.6$ was determined as the optimum solution (Figure 4). Besides, almost all of scaled residual result within the desired distribution that was \pm 3 standard deviation, in accordance with a Guide of Positive Matrix Factorization [15].

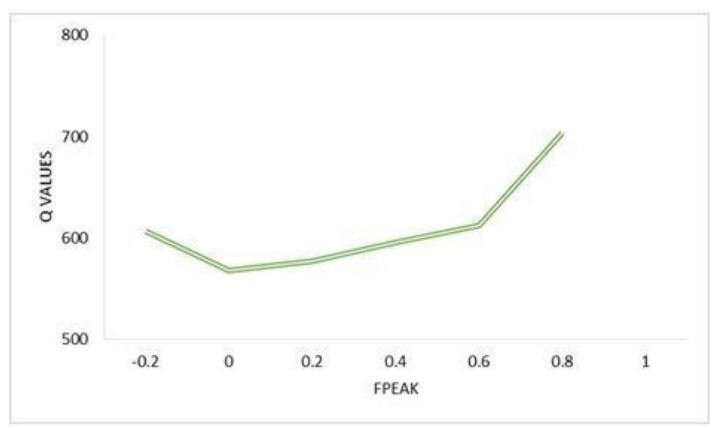

Fig. 4. Plot of $Q$ as a function of FPeak

Ten source profiles and the result of CPF are displayed in Figures 5 and Figure 6. The sources were identified as coal burning, smelting, biomass burning, iron and steel production, crustal matter, fuel oil combustion, sea salt, diesel vehicle, road dust, and cement industries and construction activity.

Element BC, S, and Si significantly appeared in the first factor. Source profile with high loading of this element was connected with emission from coal combustion [16]. The number of industries that use coal as a fuel was 
predicted contribute to the TSP concentration in the vicinity of the study.

The second factor was identified as smelting activity. It is shown from the presence of copper and titanium as the marker elements $[17 ; 7]$. The source emission was potentially predicted from the smelting process in metal industries particularly in the north-side of the study area.

Third source dominated by the presence of $\mathrm{BC}$ and $\mathrm{K}$ which were key elements of biomass burning [8]. Activity of biomass burning was estimated comes from household waste burning which was frequently done by communities in a residential area especially in the south-southwest and west-southwest of the study area. It was also demonstrated from CPF result.

The fourth source profile was potentially indicated as iron and steel production activity which was shown by Fe, $\mathrm{Al}$ and $\mathrm{Si}$ as marker elements. The biggest industry within the industrial area was iron and steel industry located on the west side until east side of the study area. It was also presented by the CPF result that shows the wind dominantly blown from the west. These emissions could be derived from the chimney as well as fugitive emissions from the storage of raw materials.

The crustal matter was identified as the fifth factor which dominated by crustal elements of $\mathrm{Al}, \mathrm{Si}$, and $\mathrm{Ti}$ [8]. This source was predicted from the crustal matter particularly from the east side. Soil dredging conducted on this side was predicted as one of the contributors.

$\mathrm{V}$ and $\mathrm{Ni}$ as marker elements of fuel oil combustion $[18 ; 19 ; 20 ; 1]$ appeared in factor six. Another study mentioned elements $\mathrm{SO}_{4}{ }^{2-}$ and $\mathrm{V}$ is a tracer of combustion of residual oil [17;7]. The emissions were probably coming from the power plant which burns residual fuel oil as a primary fuel. The power plant was located approximately $1.5 \mathrm{~km}$ northwest of the sampling sites.

The seventh factor shows the high loading of $\mathrm{Cl}, \mathrm{BC}, \mathrm{Ca}$ which were the element markers of sea salt [21]. Sunda Strait which located on the north side of the study sites was predicted as an emission source.

The presence of $\mathrm{BC}, \mathrm{Cl}-, \mathrm{SO}_{4}{ }^{2-}$ and $\mathrm{Zn}$ represent emission from diesel vehicle [8]. This source was also characterized by the element of $\mathrm{Cu}$ and $\mathrm{Si}[22 ; 1]$. Emission source likely comes from heavy vehicles passing through Raya Anyer road as the national road. The CPF plot point to north, west and south side where the national road located.

$\mathrm{Fe}, \mathrm{Cu}$ and $\mathrm{Zn}$ shows represent road dust emissions [6]. Other marker elements of the ninth factor were $\mathrm{Al}, \mathrm{Si}, \mathrm{Ti}$, $\mathrm{Fe}$ and $\mathrm{Pb}$. The National road has potentially become a source of this road dust emissions.
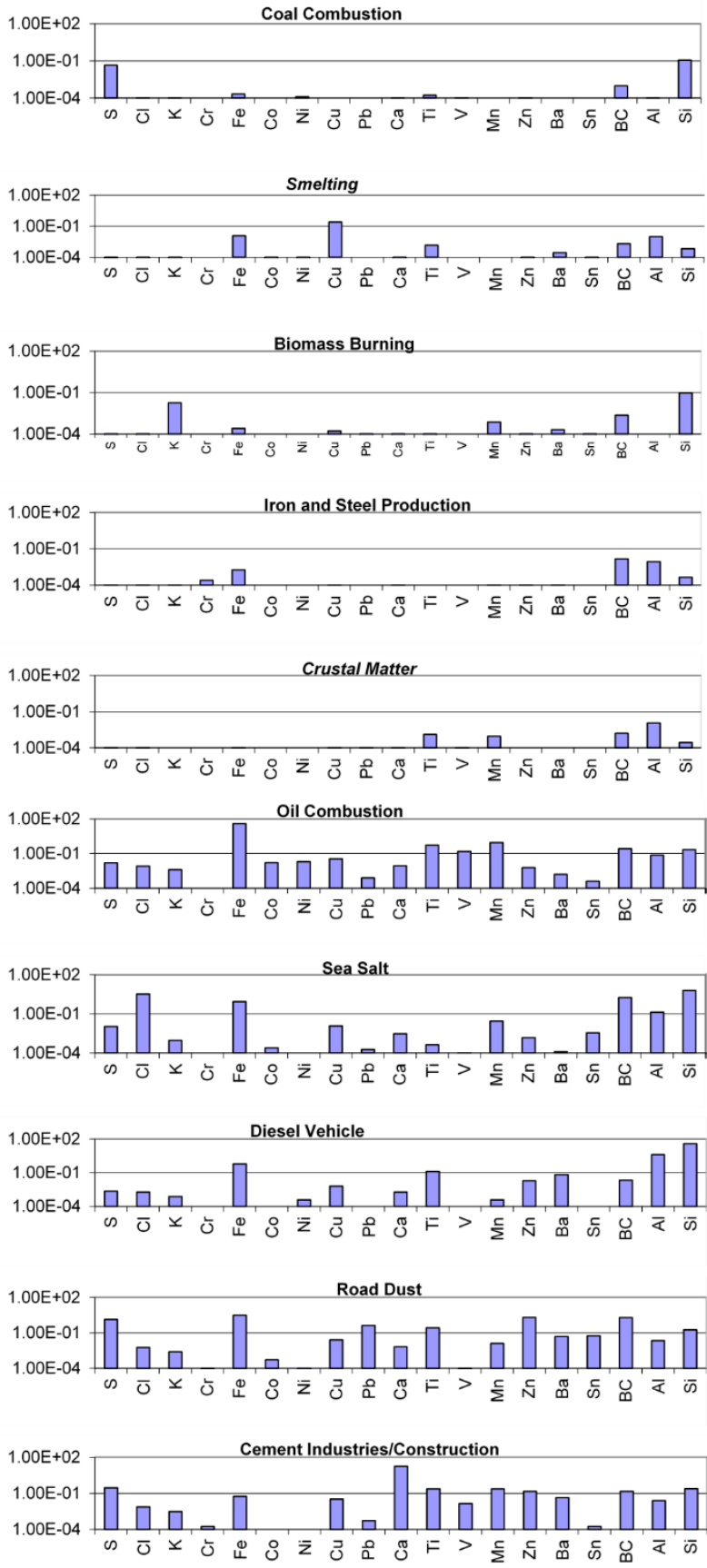

Fig 5. Source Profile

The last factor was identified as cement industry and construction activity. It was shown by the presences of the marker elements including $\mathrm{Ca}, \mathrm{Al}$ and $\mathrm{Si}$. There were construction activities surrounding study area. In addition, about $3 \mathrm{~km}$ of west side study area there were numbers of cement industries. The CPF plot points the location of cement industries and construction activities. 


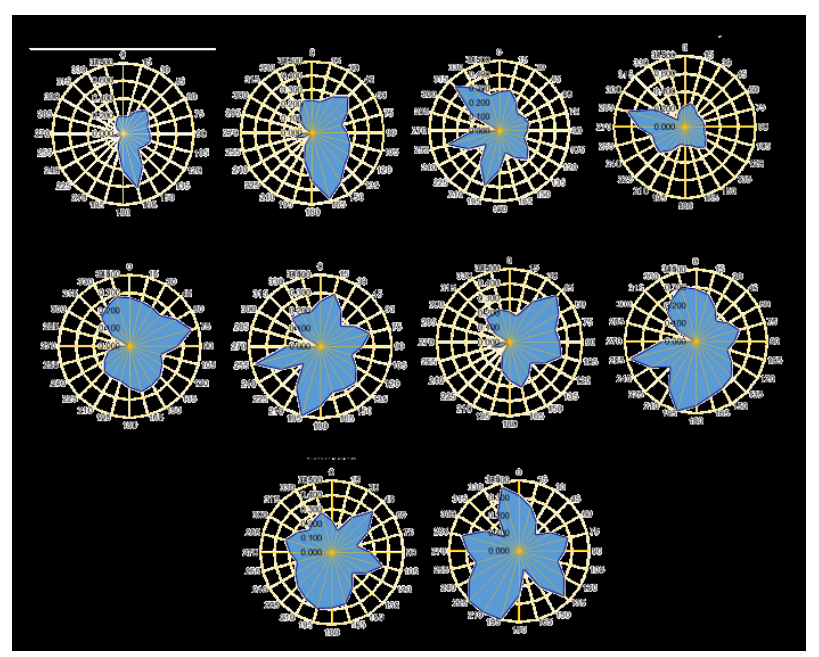

Fig.6. Result of Conditional Probability Function Analysis

\subsection{Source Contribution}

Matrix G which was an output of PMF was then multiplied by the measured mass to gain the source contribution. Figure 4 shows the contribution of each source. It can be seen that the highest contributor to TSP ambient concentration was the crustal matter which reached $40.13 \%$. It can be observed during sampling that there were dusty area and digging activity which those all were predicted as the source of crustal matter. Iron and steel production, the most extensive activity surrounding study location, was the second highest contributor which contribute to $22.23 \%$. Other major sources were coal combustion, biomass burning and smelting activity with the percentage was $16.54 \%, 11.83 \%$, and $8.63 \%$, respectively. The high rate of coal combustion and smelting activity that derived from industries were predicted as the cause why they had a significant contribution, while biomass burning was expected came from inhabitant who was frequently seen to burn their waste. Meanwhile, other identified sources had a minor effect compared to the previous sources to the TSP concentration in the ambient air. They were diesel vehicle, sea salt, fuel oil combustion, road dust, and cement industries/construction activity which only gave just under $0.3 \%$ for every source as can be seen from the Figure 7.

\section{Conclusions}

Positive Matrix Factorization was used to identify emission sources of TSP in study location. The average ambient concentration of TSP during the sampling period was $187.35 \pm$ $42.68 \mu \mathrm{g} / \mathrm{m}^{3}$ with a minimum and maximum concentration was 100.31 and $297.86 \mu \mathrm{g} / \mathrm{m}^{3}$, respectively. However, there were three samples that had concentrations exceeding the national air quality standards for Government Regulation No 41 year1999 $\left(230 \mu \mathrm{g} / \mathrm{m}^{3}\right)$. Ten factor (or sources) were found as the optimum solution resulted from PMF where the five highest contributors were crustal matter $(40.13 \%)$, iron and steel production (22.23\%), coal combustion (16.54\%), biomass burning $(11.83 \%)$, smelting $(8.63 \%)$. Meanwhile, other sources were diesel vehicle $(0.28 \%)$, sea salt $(0.17 \%)$, fuel-oil combustion $(0.07 \%)$, road dust $(0.07 \%)$ and cement industry/construction $(0.05 \%)$. The patterns of conditional probability function analysis results were adequately appropriate with the potential locations of the known sources around study site.

\section{References}

1. Kara, M., Hopke, P.K., Dumanoglu, Y., Altiok, H., Elbir, T., Odabasi, M., Bayram, A. J. Aerosol Air Qual. Res (2015)

2. Pant, Pallavi and Harrison, R.M. J. Atmos.Environ 49, 1-12 (2012)

3. Karthikeyan, S., Balasubramanian, R., Iouri, K. J. Toxicol Env Heal A 21, 1895-1908 (2006)

4. Lewtas, J. Mutat Res 636, 95-133 (2007)

5. Taiwo, Adewale Matthew, Receptor Modelling Of Industrial Air Pollutants, Thesis University of Birmingham for the Degree of Doctor of Philosophy. Division of Environmental Health Risk Management School of Geography, Earth, and Environmental Sciences University of Birmingham, 2013)

6. Rahman, S.A., Hamzah, M.S., Elias, M.S., Salim, N.A.A., Hashim, A., Shukor, S., Siong, W.B., Wood, A.K. J. Aerosol Air Qual. Res 15, 2291-2304 (2015)

7. Gupta, Indrani., Salunkhe, Abhaysinh., and Rakesh Kumar. Sci. World J. Article ID 585791 (2012)

8. Lestari, P., Mauliadi, Y.D. J. Atmos.Environ 43, 1760-1770 (2009)

9. Setyawan, I.M.H, Industrialisasi Cilegon Tahun 1962-2010, Final Project University of Malang for the Degree of Bachelor. Department of History, Faculty of Social Science University of Malang, 2011)

10. Santoso, M., Lestiani, D.D., Mukhtar, R., Hamonangan, E., Syafrul, H., Markwitz, A., Hopke, P.K. J. Atmos. Pollut. Res 2,190-196 (2011)

11. Reff, Adam., Eberly, Shelly I., Bhave, Prakash V. J. Air.Waste.Manage 57, 146-154 (2007)

12. Saxena, Mohit., Sharma, Sudhir Kumar., Mandal, Tuhin Kumar., Singh, Sachchidanand.,

Fig.7. Source contribution 
Saud, Trailokya. J. Atmos. Pollut. Res 5, 729740 (2014)

13. Polissar, Alexander V., Hopke, Philip K., Paatero, Penti. J. Geophys. Res 103, 1904519057 (1998)

14. Owoade, Kayode.O., Hopke, Philip.K., Olise, Felix.S., Ogundele, Lasun.T., Fawole, Olusegun.G., Olaniyi, Bamidele.H., Jegede, Olugbemiga.O., Ayoola, Muritala.A., Bashiru, Muniru.I. J. Atmos. Pollut. Res 6, 107-119 (2015)

15. Hopke, Philip.K, A guide to positive matrix factorization.(Department of Chemistry Clarkson University Potsdam, New York ,2000)

16. Cohen, D.D., Crawford, Jagoda., Stelcer, Eduard., and Bac, Vuong Thu. J. Atmos.Environ 44, 320-328 (2010)

17. J. G. Watson et al., Protocol for applying and validating the $C M B$ model for $P M_{2.5}$ and VOC. US Environmental Protection Agency, Air Quality Modeling Group, 2004)

18. Kim, E. and Hopke, P.K. J. Air.Waste.Manage 54, 773-785 (2004)

19. Mazzei, F., D'Alessandro, A., Lucarelli, F., Nava, S., Prati, P., Valli, G. and Vecchi, R. Sci.Total. Environ 401, 81-89 (2008)

20. Kocak, M., Mihalopoulos, N. and Kubilay, N. J. Atmos.Res 92, 464-474 (2009)

21. Seneviratne, M.S.C., Waduge, V.A., Hadagiripathira, L., Sanjeewani, S., Attanayake, T., Jayaratne, N., Hopke, P.K., 2011. J. Atmos. Pollut. Res 2, 207-212 (2011)

22. Lee, J.H. and Hopke, P.K. J. Atmos.Environ 40, S360-S377(2006) 